\title{
Sprawozdanie z sympozjum Wolniewiczowskiego
}

\author{
Mateusz Pencuła \\ (Uniwersytet Warszawski, Instytut Filozofii)
}

Dnia 14 września 2018 r. w nastrojowych pomieszczeniach piwnic Teatru Kamienica w Warszawie odbyło się sympozjum z okazji 91. rocznicy urodzin Profesora Bogusława Wolniewicza, pt. „Inspiracje myślą Bogusława Wolniewicza w rok po jego śmierci". Spotkanie zostało zorganizowane przez rodzinę Profesora - córkę dr Ewę Wolniewicz-Warską oraz wnuki - Lidię Kaźmierczak i Adama Warskiego. Wśród zaproszonych znaleźli się współpracownicy prof. Wolniewicza: prof. Zbigniew Musiał i prof. Mieczysław Omyła; jego słuchacz i admirator stylu myślowego - prof. Jacek Jadacki; uczniowie i uczestniczy zajęć prowadzonych przez prof. Wolniewicza: dr hab. Jan Zubelewicz, prof. PW, dr hab. Paweł Okołowski, dr Jędrzej Stanisławek, mgr Marek Kądzielski; także redaktor naczelny „Najwyższego Czasu!” (w którym Profesor publikował przez wiele lat) - dr Tomasz Sommer; Leszek Niewiński (znajomy, który - jak to określił Paweł Okołowski - „towarzyszył Bogusławowi Wolniewiczowi i wspierał go we wszystkich rozprawach sądowych”) oraz „uczniowie uczniów”: mgr Anna Zalewska i dr Mateusz Pencuła. Gośćmi byli także znajomi Profesora z kręgów nie akademickich, a raczej rodzinnych. Łącznie stawiło się ponad 20 osób.

Spotkanie rozpoczęło się o godz. 17.00 powitaniem zebranych przez Ewę Wolniewicz-Warską i wyrażeniem wdzięczności, że w tak szacownym gronie możliwe było uczczenie urodzin jej Ojca (przypadających 22 IX). Następnie rozpoczęła się oficjalna część uroczystości, złożona z krótkich (od 10-cio do 20-minutowych) wystąpień. Pierwszy zabrał głos prof. Zbigniew Musiał, od 50 lat znajomy, a od ponad 40 przyjaciel i współpracownik Wolniewicza w IF UW. Wspomniał on, że gdyby nie Wolniewicz, zapewne z filozofią w ogóle by się nie związał. Po prze- 
rwaniu studiów w Leningradzie (1955-1958), w zakresie filozofii i fizyki, dalszą edukację kontynuował na Wydziale Filozofii UW. W latach 60-tych dominowała tu fascynacja egzystencjalizmem i fenomenologią. Retoryka tych nurtów dawała mu poczucie, że „cała ta filozofia to chyba nie na jego - Musiała - głowę”. Już jako asystent myślał nawet o poszukaniu sobie innej pracy. Dopiero spotkanie z Bogusławem Wolniewiczem spowodowało, że zmienił zdanie. Dostrzegł w pismach i w postawie Wolniewicza precyzję myśli oraz hierarchię spraw, tak różne od marnego stylu filozofii wokół. Wolniewicz nakłonił Musiała do napisania wspólnego artykułu Psychotronika jako neookultyzm (1975), i tak zaczęła się ich długa i owocna współpraca naukowa. Prof. Musiał wspominał także o kulisach powstawania książki Ksenofobia i wspólnota (2003) oraz ogólnie - o ich metodzie pisania we dwóch jednolitego tekstu akademickiego. „Język Wolniewicza - zwłaszcza ten wyrażany w tonacji $C$-dur i allegro - uznałem za wzorcowy", mówił - „dlatego postanowiłem swój styl całkowicie podporządkować tamtemu”.

$\mathrm{Na}$ żartobliwe wtrącenie Pawła Okołowskiego - że tandem filozoficzny Wolniewicz-Musiał jest historycznie czymś tak rzadkim, iż studenci umieją go porównać jedynie do duetu Marks-Engels - odparł anegdotą. Otóż kiedy w czasach odwilży w ZSRR, za Chruszczowa, dzieci zwiedzające muzeum historii naturalnej stanęły przed wieńczącymi ekspozycję szkieletami paleolitycznych ludzi mężczyzny i kobiety, przewodnik zapytał: czy wiedzą czyje to szkielety? Jedno z dzieci rzekło nieśmiało: czyżby Marksa i Engelsa?

Drugim prelegentem był prof. Mieczysław Omyła. Przypomniał, że myśl Wolniewicza (dotycząca Traktatu Wittgensteina) w latach 60. zainspirowała Romana Suszkę do stworzenia jego logiki niefregowskiej. Dalej mówił o tym, jak myśl Wolniewicza inspirowała jego, także przez rok, który upłynął od śmierci Profesora. Wygłosił on, między innymi, na 63 Konferencji Historii Logiki w Krakowie referat zatytułowany $O$ Bogusławie Wolniewiczu z bliska. Zaznaczył, że Konferencje Historii Logiki w Krakowie cieszyły się wielkim uznaniem prof. Wolniewicza; że był ich częstym uczestnikiem i uważał za ostatni bastion racjonalności w Polsce. Następnie prelegent wspomniał, że złożył cztery artykuły dedykowane Zmarłemu: Logika diachroniczna a logika niefregowska i O metafizyce sytuacji (do „Edukacji Filozoficznej”) oraz Moja wspótpraca z Profesorem Bogusławem Wolniewiczem i O ontologii sytuacji (do „Przeglądu Filozoficznego”).

Trzeci prelegent - prof. Jacek Jadacki - zaczął od pięknego porównania okrągłych okien (z motywami pofałdowanej wody), umieszczonych na okład- 
kach czterech tomów Filozofii i wartości Wolniewicza, do rozet nad portalami gotyckich katedr. Wskazawszy literalny sens tych rozet-metafor i podkreśliwszy, że uważa Wolniewicza za myśliciela wybitnego - poddał krytyce niektóre jego poglądy, uznając je za przejaw (jak to określił) inspiracji negatywnej, którą zawdzięcza Profesorowi. Zanalizował w szczególności podane przez Wolniewicza cztery kryteria bycia-teorią (postulat dedukcyjności teorii oraz nieoczywistości, konsensualności i satysfakcjonującego uzasadnienia jej tez) i opatrzył te kryteria komentarzami polemicznymi.

Po krótkiej przerwie na zaczerpnięcie oddechu i rozprostowanie nóg, tuż po godz. 18.00, referat wygłosił dr hab. Jan Zubelewicz, prof. PW, uczeń Wolniewicza od lat 70. Rozważania Wolniewicza i Musiała w sprawie relacji między wspólnotą i ksenofobią zainspirowały go do dalszych przemyśleń. Wyróżnił on dwa podstawowe podziały polityczne świata: na państwa oraz na strefy wpływów i strefy buforowe. W danej strefie wpływów protektor ustala pewne zasady preprawne, w tym też rozumienie ksenofobii. Faktycznie istnieje pewien poziom ksenofobii protektora wobec wasala oraz wasala wobec protektora. Jednak w swoich deklaracjach protektor $\mathrm{z}$ reguły twierdzi, że nie odczuwa ksenofobii wobec wasala, może nawet mówić, że go kocha. Z drugiej strony protektor wyolbrzymia ksenofobię wasala. Deklarowana walka z ksenofobią służy zmniejszeniu ksenofobii wasala wobec protektora i zwiększeniu ksenofobii protektora wobec wasala.

Kolejny mówca - dr Jędrzej Stanisławek z PW (określający siebie jako kometę, od lat 70. orbitującą - raz bliżej, raz dalej - wokół Wolniewicza) poruszył dwie kwestie. Pierwszą wyraża pytanie: „czy Wolniewicz, uchodzący za nieludzko srogiego, miał ludzkie uczucia"? W odpowiedzi - twierdzącej - przytoczona została historia o czułym stosunku Profesora do wnuków. Kwestią drugą był stosunek Wolniewicza do bólu w ogóle - rygorystycznie nastawiony na jego zwalczanie, także u zwierząt. Dr Stanisławek przypomniał słowa Profesora: „buddyzm z całą swoją nauką uwalniania człowieka od cierpienia mniej w tej sprawie zrobił niż jeden europejski dentysta”. Na koniec Ewa Wolniewicz-Warska dodała, że jako córka może jednoznacznie zaświadczyć, że Bogusław Wolniewicz miał „ludzkie uczucia”, choć był osobą niezwykle surową.

Następnie głos zabrał Leszek Niewiński (syn płk. Jana Niewińskiego, znanego obrońcy Wołynia), były marynarz i dobry, od lat 80., znajomy Profesora i jego uczniów. W umiejętny sposób własnym stylem rozładował gęstniejącą już atmosferę naukowego posiedzenia. Opowiedział kilka anegdot związanych z osobą 
Prof. Wolniewicza, na przykład historię pośmiertnego popiersia prof. Ulricha Schradego (wykonanego na prośbę przyjaciół przez artystę plastyka Włodzimierza Fruczka). Wolniewicz, gdy rzeźbę obejrzał, rzekł: „nadawałaby się do ambasady USA, bo gdyby bokobrody doprawić, byłby Abraham Lincoln”. Artysta swą rzeźbę poprawił. Wolniewicz przy tym zaś ubolewał, że nigdzie nie spotkał dobrze wykonanego pomnika Jana Pawła II. Niewiński zaznaczył też, że Profesor zawsze uprzejmie odnosił się do prostych a trzeźwo myślących ludzi.

Jako czwarty w drugim bloku wystąpień głos zabrał red. Tomasz Sommer (niegdyś uczestnik zajęć Wolniewicza w UW, później adresat jego listów do redakcji i częsty rozmówca). Podkreślał on fakt, że „późny Wolniewicz” zmienił znacznie swój stosunek do estetyki, uznając piękno (niegdyś przez siebie lekceważone) za rzecz pierwszoplanową. „Piękno” - mówił Profesor w ostatnich latach - „jest głównym środkiem komunikacji pomiędzy kulturami - jest uniwersalne, inaczej, na przykład, niż nasz zachodni racjonalizm".

Po drugiej krótkiej przerwie, po godz. 19.00, słowo wygłosił uczeń (od 1985 r.) Wolniewicza - dr hab. Paweł Okołowski. Wystąpienie dotyczyło Profesora znanej idei prawo- i lewoskrętności - arcyważnej a niedokończonej, bo skwitowanej otwartym pytaniem: „dlaczego lewoskrętni wiodą we współczesnym świecie Zachodu prym i stanowią większość?”. Okołowski podjął się eksplikacji zagadnienia, jednak ze względu na ograniczony czas, z 20 przygotowanych tez podał i omówił trzy. Otóż lewo- i prawoskrętność, jako osobowe skłonności, bywają wrodzone, ale i nabyte. Są więc leworodni, lewowierni, praworodni i prawowierni. Wrodzone spośród tych dyspozycji tożsame są z osobowym stosunkiem do śmierci - opartym w pierwszym przypadku na strachu, a w drugim na rozpaczy. Większość populacji nie jest leworodna, a tylko współcześnie lewowierna. Walka z jej wiarą nie jest więc, mimo złych widoków, beznadziejna. Jest dla natury ludzkiej naturalna.

Jako dziewiąty mówca wystąpił kolejny dawny uczestnik zajęć Wolniewicza w IF UW mgr Marek Kądzielski (dziś tłumacz przysięgły, który spolszczył m.in. książkę Power Russella). Wspominał pierwszy kontakt (w 1984 r.) ze stylem myślowym Profesora, który odcisnął na nim potężne piętno i na zawsze już pozostał niedościgłym. Mówił również o swoich częstych rozmowach prywatnych z Wolniewiczem, w których Profesor bywał jego powiernikiem. Zwierzył się, że w najgorszych sytuacjach życiowych - śmierci bliskich - dzwonił do Profesora i uzyskiwał pociechę. Nie jakiś duchowny, ale Wolniewicz był dlań pierwszym 
„specjalistą od śmierci”. Na zakończenie usłyszeliśmy „jak bardzo dziś Profesora brakuje" - i intelektualnie, i emocjonalnie.

Z kolei swój krótki referat - o istocie zła moralnego według Jonathana Edwardsa - w nawiązaniu do Wolniewiczowskiej antropologii wygłosiła mgr Anna Zalewska. Pracuje ona nad doktoratem z myśli Edwardsa - XVIII-wiecznego, kalwina-analityka, którego Wolniewicz miał za pierwszy umysł filozoficzny Ameryki, a doktoratowi temu kibicował.

Jako ostatni wystąpił zaś dr Mateusz Pencuła. W oparciu o pośmiertnie wydaną książkę profesora Polska a Żydzi (2018) wskazał na doniosłość publicystycznej twórczości Wolniewicza, którą określił, jako „dzieło, z punktu widzenia filozoficznego, mniejszego kalibru niż rozważania prowadzone na stronach Filozofii $i$ wartości, jednak nie mniej wartościowe”. Wolniewicz-publicysta przedstawiony został jako mistrz krytycznego myślenia o sprawach codziennych i dotyczących każdego Polaka, takich jak relacje polsko-żydowskie czy kwestia politycznej poprawności. Z kart artykułów publicystycznych profesora wyłania się postać nauczyciela, który dąży nie tylko do prawdy, ale także do zawrócenia czytelnika $\mathrm{z}$ „owczego pędu” - zmuszenia go do samodzielnej refleksji w odniesieniu do informacji, którymi „bombardowany” jest przez współczesne media. Podsumowując swoje wystąpienie, Pencuła wspomniał - nawiązując do tematu sympozjum że „Bogusław Wolniewicz inspiruje nas do samodzielnego myślenia i wyciągania wniosków; inspiruje nas do tego, abyśmy nie dali sobie zamknąć ust i walczyli o podstawowe prawo, które winno nam przysługiwać w demokratycznym świecie Zachodu - prawo do wolności słowa i wolności myśli”.

$\mathrm{Na}$ zakończenie oficjalnej i merytorycznej części sympozjum ponownie głos zabrał prof. Musiał, mówiąc jak i jemu brak jest dzisiaj Profesora - a głównie jego przyjaźni.

Po części merytorycznej, ok. godz. 20.00, nastąpiło nieoficjalne dopełnienie spotkania przy barowych stolikach. W swobodniejszej atmosferze komentowano referaty, ale też wznoszono toasty - między innymi, za szybkie i udane reedycje 5 książek Profesora (3 tomy Filozofii $i$ wartości planują wznowić Wydawnictwa UW, a 2 tytuły o Wittgensteinie ma znów wydać PWN) oraz za dobry los numeru Wolniewiczowskiego (3/2018), szykowanego przez „Przegląd Filozoficzny”. Rozmowy w kuluarach dotyczyły zarówno spraw wielkiej filozoficznie wagi, jak i tych zupełnie doczesnych. Uroczystość zakończyła się po godzinie 21.00. Sympozjum pokazało, że wieloaspektowa myśl Profesora Bogusława Wolniewicza 
jest niezwykle żywa, a jego osoba nadal intrygująca, choć jakby dziś bliższa przez jej niepowetowane zniknięcie. Środowisko uczniów i sympatyków Profesora miało tu też okazję zamanifestować swoją intelektualną obecność i odrębność. A gospodarze zapowiedzieli powtórzenie takiej okazji za rok. 